\title{
ОСНОВНЫЕ НАПРАВЛЕНИЯ ПРИМЕНЕНИЯ ЦИФРОВЫХ МЕТОДОВ И ТЕХНОЛОГИЙ В ТАМОЖЕННОЙ СФЕРЕ: ПРАВОВЫЕ ВОПРОСЫ *
}

\author{
(C) 2019 Бакаева Ольга Юрьевна \\ доктор юридических наук, профессор \\ профессор кафедры финансового, банковского и таможенного права \\ Саратовская государственная юридическая академия (СГЮА) \\ 410056, г. Саратов, Вольская ул., д. 1 \\ E-mail: finpravo@ssla.ru \\ (c) 2019 Устинова Анастасия Васильевна \\ кандидат юридических наук \\ старший преподаватель кафедры финансового, банковского и таможенного права \\ Саратовская государственная юридическая академия (СГЮА)

$$
\begin{aligned}
& \text { 410056, г. Саратов, Вольская, д.1 } \\
& \text { E-mail: finpravo@ssla.ru }
\end{aligned}
$$

В статье рассмотрены правовые вопросы применения цифровых методов и технологий в таможенной сфере, их значение в деятельности таможенных органов Российской Федерации и участников ВЭД.

Ключевые слова: иифровые методы в таможенной сфере; цифровые технологии в таможенной сфере; личный кабинет участника ВЭД; электронные таможни; удаленная уплата таможенных платежей; информационная безопасность.

Государственное регулирование внешнеторговой деятельности предполагает, в частности, необходимость создания аппарата, на который государством возлагаются функции по контролю и надзору за перемещением товаров через границу. Таможенные органы обеспечивают соблюдение правил, регулирующих таможенные отношения, при этом такие правила не должны быть слишком сложными, запутанными, неудобными; иначе они будут тормозить процесс развития внешней торговли. Упрощение таможенных формальностей предполагает максимальное использование информационных технологий, развитие которых происходит стремительными темпами. Таможенная служба применяет их в тех случаях, когда это экономически выгодно и эффективно не только для нее, но и для частных субъектов. Такое правило установлено в главе 7 Международной (Киотской) конвенции об упрощении и гармонизации таможенных процедур [13]. Упрощение таможенного регулирования и снижение административных барьеров в этой области является и одним из направлений реализации Стратегии развития отрасли информационных технологий в Российской Федерации [29].

Возрастающая нагрузка на таможенные органы во всем мире, обусловленная увеличением объемов внешнеэкономической деятельности, развитием интернет-торговли, расширением возможностей для трансграничных перевозок обусловливает повышение значимости совершенствования информационных технологий и систем для таможенного дела. Формирование позитивного имиджа российских таможенных органов осуществляется, в том числе посредством информационной деятельности; данное начало положено в основу устойчивого развития таможенной службы Российской Федерации [31]. В науке справедливо отмечается, что совершенствование информационных технологий в таможенной сфере направлено на повышение таможенными органами «клиентоориентированности», с одной стороны, и повышение добросовестности хозяйствующих субъектов - с другой [14].

Активное внедрение информационных технологий способствует повышению контроля над

\footnotetext{
* Исследование выполнено при финансовой поддержке РФФИ в рамках научного проекта № 18-29-16102 «Трансформация правосубъектности участников налоговых, бюджетных и публичных банковских правоотношений в условиях развития цифровой экономики»
} 
участниками внешнеэкономической деятельности (далее - ВЭД), а также значительному ускорению процесса таможенного оформления и контроля. Цифровые методы и технологии позволяют улучшить показатели эффективности деятельности таможенных органов Российской Федерации, создать систему комплексного учета и анализа участников ВЭД, а также уменьшить случаи злоупотребления полномочий при принятии решений должностными лицами таможенных органов. Кроме того, благодаря применению информационных технологий осуществляется информационно-аналитическое обеспечение правоохранительной деятельности в таможенной сфере. Данная сфера деятельности очень серьезна и охватывает большой объём информации, которую необходимо вовремя обработать и сохранить, что весьма затруднительно без информационных технологий [4].

Среди федеральных органов исполнительной власти Федеральная таможенная служба занимает лидирующую позицию в вопросах цифровизации своей деятельности. В целях содействия развитию внешнеэкономической деятельности, минимизации издержек участников ВЭД и государства, связанных с совершением таможенных операций, дальнейшему повышению качества таможенного администрирования проводится планомерная работа по развитию информационно-технического обеспечения таможенных органов. По своему составу таможенная информационная система подобна предприятию по переработке данных и производству итоговой информации. Каждое должностное лицо таможенных органов выполняет свои обязанности и передает их другому для непрерывного процесса «производства» [11]. По внедрению новых технологий таможенные органы занимают одно из первых мест в числе иных органов публичной власти. Идя навстречу добросовестным участникам ВЭД, разрабатываются оптимальные пути решения проблем, связанных с унификацией таможенных процедур и переходом работы таможни на уровень международных стандартов.

Применением в таможенной сфере информационных технологий государство озаботилось еще в 2005 году, когда в Концепции развития таможенных органов Российской Федерации [30] были обозначены такие приоритеты, как: повышение эффективности таможенного контроля и борьбы с таможенными правонарушениями на основе создания комплексной системы учета участников ВЭД и анализа их деятельности; информационно-аналитическое обеспечение правоохранительной деятельности в таможенной сфере и внедрение комплексной системы управления рисками, развития системы электронного декларирования.

В настоящее время данному вопросу в Российской Федерации и в Евразийском экономическом союзе, участником которого является наше государство, уделяется первоочередное внимание.

Таможенное регулирование в ЕАЭС основывается на принципе максимального использования информационных технологий в деятельности таможенных органов. Данный принцип прямо установлен в п.3 ст.1 Таможенного кодекса Евразийского экономического союза [40] (далее - ТК ЕАЭС) Это неотъемлемая составляющая в реализации современной таможенной политики.

Понятие информационных технологий не получило единообразного толкования в науке, однако в самом общем виде это совокупность способов, методов, средств, приемов сбора, получения, обобщения и обработки информации [2]. Для их функционирования необходимо правовое, организационное и материально-техническое обеспечение, то есть соответственно: правовые нормы, регулирующие порядок применения таких технологий; аппарат, использующий их; технические средства и возможности (например, программное обеспечение), позволяющие осуществлять необходимую деятельность. В настоящее время совершен переход от аналоговых к цифровым информационным системам, используемым практически повсеместHo.

В таможенной сфере информатизация включает применение необходимых технических средств (например, технических средств таможенного контроля); информационных систем (например, ресурс «Личный кабинет участника ВЭД»); информационных технологий (например, удаленная уплата таможенных платежей). Одни из них - к примеру, инспекционно-досмотровые комплексы - используются достаточно давно, другие появились только в последние годы, третьи только начинают создаваться.

В международных основах таможенного регулирования также указывается значимость информатизации. На основании Стандартных правил Генерального приложения к Междуна- 
родной конвенции об упрощении и гармонизации таможенных процедур закреплена возможность представлять таможенным органам декларацию на товары в электронном виде посредством электронных способов обмена (стандарт 7.4).

Особую роль информационных технологий в таможенном деле подчеркивает тот факт, что в ТК ЕАЭС включен отдельный раздел, посвященный информационным системам и технологиям. Под информационными ресурсами таможенных органов понимается упорядоченная совокупность документированной информации (базы данных, другие массивы информации), содержащейся в информационных системах таможенных органов. Положения о возможности применения информационных технологий в таможенной сфере содержатся во многих нормах кодекса: о доведении таможенными органами информации до общего сведения (ст.3); о предварительном информировании (ст.11); о представлении документов и сведений для совершения таможенных операций (ст.80); о совершении таможенными органами отдельных таможенных операций (ст.ст.82, 92, 118, 125); о помещении товаров под таможенную процедуру таможенного транзита (ст.ст.147, 150, 151); о таможенном контроле (ст.ст. 310, 318, 324, 333, 344) и пр.

Введенный в законную силу 1 января 2018 года кодекс, по сути, легализовал цифровые технологии (кодекс оперирует более широким понятием - информационные технологии), которые в настоящее время в Российской Федерации уже применяются на практике: предварительное информирование, электронное декларирование, автоматический выпуск товаров. Такая легализация необходима в первую очередь для эффективного взаимодействия с другими государственными, в том числе налоговыми, правоохранительными органами.

Применение в таможенной сфере современных цифровых методов и технологий предопределено не только целесообразностью упрощения таможенных формальностей, но и не необходимостью тесного взаимодействия государств-членов ЕАЭС. Без надлежащей координации их деятельности невозможно добиться целей, ради которых таможенные органы и были созданы. Безусловно, такое взаимодействие в настоящее время требует максимальной оперативности, что означает замену бумажного до- кументооборота электронным. В данной связи в 2014-2015 годах Евразийской экономической комиссией были приняты основные документы, определяющие правила электронного обмена данными, подходы к использованию при межгосударственном информационном взаимодействии сервисов и имеющих юридическую силу электронных документов, порядок ведения и применения реестра структур электронных документов и сведений, методику анализа, оптимизации, гармонизации и описания общих процессов, правила создания и ведения единой системы нормативно-справочной информации Союза.

С 2014 г. ведется реестр структур электронных документов и сведений, используемых при реализации информационного взаимодействия в интегрированной системе (https://rseds. eurasiancommission.org/). Создан реестр электронных ресурсов единой системы нормативно-справочной информации Союза (https://nsi. eurasiancommission.org/).

В дальнейшем была поставлена задача создания единой (в рамках ЕАЭС) системы, предназначенной для обеспечения межгосударственного обмена документами и сведениями, создания общих для государств-членов ЕАЭС информационных ресурсов, реализации общих процессов. Такая система, получившая название интегрированной, предполагает обеспечение поддержки по всем направлениям, включая таможенное регулирование, поскольку именно таможенные органы в силу трансграничного характера их деятельности и деятельности на основе унифицированных правовых норм должны взаимодействовать между собой.

В целях создания благоприятных условий для хозяйствующих субъектов государств-членов ЕАЭС, обеспечения эффективного регулирования внешней и взаимной торговли на единой таможенной территории ЕАЭС, осуществления таможенного, налогового, транспортного контроля и государственного контроля других видов с использованием информационно-телекоммуникационных технологий, обеспечения реализации процессов экономической интеграции, организации эффективной работы органов государств - членов ЕАЭС в соответствии с Соглашением о создании, функционировании и развитии интегрированной информационной системы внешней и взаимной торговли Таможенного союза от 21 сентября 2010 г. и Концеп- 
цией создания Интегрированной информационной системы внешней и взаимной торговли Таможенного союза, утвержденной Решением Межгосударственного совета Евразийского экономического сообщества от 19 ноября 2010 г., была организована работа по созданию интегрированной информационной системы внешней и взаимной торговли [37].

В нашей стране основные направления развития информационно-коммуникационных технологий в таможенных органах Российской Федерации определены на период до 2030 года [26]. Уже в настоящее время информационно-коммуникационные технологии, используемые в деятельности российских таможенных органов, способствуют развитию внешнеэкономической деятельности и дальнейшему повышению качества таможенного администрирования. Их применение обеспечивает автоматизацию процесса поступления доходов в федеральный бюджет, минимизирует издержки для участников ВЭД, связанные с совершением таможенных операций, обеспечивает соблюдение запретов и ограничений, а также защиту отечественных производителей и охрану объектов интеллектуальной собственности.

Информационные системы и информационные технологии используются таможенными органами в целях обеспечения выполнения возложенных на них задач, в том числе обмена информацией с федеральными органами исполнительной власти, оказания государственных услуг населению, участникам ВЭД по предоставлению информации в электронном виде (ст. 31 Федерального закона «О таможенном регулировании в Российской Федерации и о внесении изменений в отдельные законодательные акты Российской Федерации» [42] (далее - Закон о таможенном регулировании).

Создание новых концепций в таможенном деле тесно связано с переходом от автономных информационных систем таможен к Единой автоматизированной информационной системе (далее - ЕАИС) таможенных органов [24].

ЕАИС - централизованная система управления процессами таможенной деятельности; она состоит из организационно упорядоченной совокупности документов или массивов документов и информационных технологий, в том числе с использованием средств вычислительной техники и связи, реализующих информационные процессы на всех уровнях системы таможенных органов. Цель ее создания - автоматизация процессов совершения таможенных операций, а ее использование обеспечивает реализацию возложенных на Федеральную таможенную службу (далее - ФТС России) функций и полномочий в области таможенного дела. Система используется при таможенном контроле, таможенном декларировании и выпуске (отказе в выпуске) товаров, помещаемых под таможенную процедуру таможенного транзита, в электронной форме [23, 25]. Очевидно, что применение такой технологии позволяет упростить процесс подготовки и принятия решения о выпуске товара, сделать его более прозрачным для бизнеса.

В настоящее время определены основные направления применения в таможенной сфере информационных технологий:

1) электронное декларирование;

2) предварительное информирование;

3) автоматическая регистрация деклараций;

4) удаленный выпуск товаров;

5) удаленная уплата таможенных платежей;

6) предоставление государственных услуг (функций) в электронном виде;

7) и др.

Внедрение электронного таможенного декларирования в Российской Федерации шло поэтапно. Первым законодательным шагом в этой области можно считать принятие в 2002 г. Федерального закона «Об электронной цифровой подписи» [43]. С этого момента электронная подпись была приравнена к собственноручной, а значит, открылась возможность для передачи таможенных деклараций, подписанных электронным способом.

Очевидно, что специалистами механизм совершенствования технологии декларирования был поддержан, поскольку и для таможенных органов, и для участников ВЭД он стал основным критерием, обеспечивающим сокращение времени на прохождение таможенных формальностей, уменьшение издержек, а значит, и увеличение прибыли [5]. Создание электронного документооборота позволило усилить прозрачность действий таможенных органов, а также исключить один из важных коррупциогенных факторов - личный контакт должностного лица таможенного органа с декларантом. Тем самым был снижен риск влияния различных субъективных факторов на процесс таможенного деклари- 
рования.

Первая в России электронная таможенная декларация была выпущена 25 ноября 2002 г. по технологии ЭД-1 (подключение по выделенному каналу связи). Поскольку в этом случае участнику ВЭД приходилось нести существенные финансовые затраты, то объемы поданных в электронной форме деклараций были незначительны. К 2008 г. на них приходилось не более 9\% от общего количества деклараций [17].

Переход на систему электронного декларирования был обусловлен стабильным ростом объема внешнеэкономических операций, а значит, и потока документации через таможенные органы, одна из основных задач которых - обеспечение оперативного (в максимально сжатые сроки) оформления товаров. Достичь этого возможно посредством перехода на электронный документооборот.

В 2010 г. с образованием Таможенного союза появилась необходимость законодательного закрепления на наднациональном уровне технологии электронного декларирования, в связи с чем была разработана инструкция о порядке предоставления и использования таможенной декларации в виде электронного документа [35]. Параллельно с этим таможенными органами проводилась активная работа по разъяснению частным субъектами преимуществ электронного декларирования.

В последующие годы ФТС России проводился постоянный мониторинг практики электронного декларирования, а соответствующая информация регулярно публиковалась на ее официальном сайте в соответствии с Концепцией открытости федеральных органов исполнительной власти.

С 1 января 2014 г. в Российской Федерации было введено обязательное электронное декларирование товаров (п.4 ст.322 ранее действовавшего Закона о таможенном регулировании [41]).

Установленный в настоящее время в ТК ЕАЭС приоритет электронной формы представления документов, внедрение в практику работы таможенных органов технологий, базирующих на электронном взаимодействии с федеральными органами исполнительной власти, участниками ВЭД и иными заинтересованными лицами, ведет к пересмотру применяемых технологий, совершения таможенных операций и модернизации программных средств.

На основании п. 2 ст. 80 ТК ЕАЭС документы и сведения, необходимые для совершения таможенных операций, могут не представляться таможенному органу при их совершении, если сведения о таких документах, и сведения из них, и иные сведения, необходимые таможенным органам для совершения таможенных операций, могут быть получены таможенными органами из информационных систем таможенных органов (организаций) государств-членов ЕАЭС в рамках информационного взаимодействия таможенных органов и государственных органов (организаций) государств-членов ЕАЭС.

Именно электронное декларирование дало старт применению современных информационных технологий, таких как предварительное информирование, автоматическая регистрация деклараций, а также технология удаленного выпуска товаров. Применяемые перспективные таможенные технологии позволили расширить уровень информационного взаимодействия между таможенными органами и участниками ВЭД, обеспечили автоматическую обработку сведений, содержащихся в представляемых документах, а также повысили оперативность принятых решений.

Одним из направлений перспективных векторов развития таможенных информационных технологий является предварительное информирование. Оно используется таможенными органами для ускорения совершения таможенных операций и оптимизации проведения таможенного контроля. Исходя из названия, можно понять, что таможенные органы получают от декларанта информацию о ввозимых товарах заранее, до момента пересечения ими границы, что позволяет провести отдельные проверочные мероприятия заблаговременно.

В 2006 году Федеральной таможенной службой были определены приоритеты создания системы предварительного информирования:

1) создание условий для транспорентности и предсказуемости действий таможенных органов;

2) минимизация времени выполнения таможенных формальностей в пунктах пропуска через Государственную границу РФ и местах оформления;

3) повышение оперативности управления таможенными органами и эффективности принятия решений должностными лицами таможенных органов посредством предварительного определения товаров, транспортных средств, 
документов и лиц, подлежащих проверке, и степени такой проверки;

4) оптимизация деятельности таможенных органов, распределения людских и материальных ресурсов [8].

Уже в это время устанавливалась возможность использования для предварительного информирования Единой автоматизированной информационной системы таможенных органов.

В 2010 году был создан портал предварительного электронного представления сведений физическими лицами в таможенные органы [21]. Затем данная система стала постепенно внедряться для товаров с учетом способа их перемещения. Введение с июня 2012 г. обязательного предварительного информирования о товарах, ввозимых на таможенную территорию ЕАЭС автомобильным транспортом [36], позволило в среднем на 30 мин сократить время, необходимое для проведения государственного контроля в пунктах пропуска [12].

Общие правила представления предварительной информации определяются ст. 11 ТК ЕАЭС. Данный метод применяется в целях получения таможенными органами сведений о товарах, планируемых к перемещению через таможенную границу ЕАЭС, для оценки рисков и принятия предварительных решений о выборе объектов, форм таможенного контроля и мер, обеспечивающих проведение таможенного контроля, до прибытия товаров на таможенную территорию ЕАЭС. Компетенциями по принятию ряда решений в рамках предварительного информирования обладает Евразийская экономическая комиссия. В настоящее время ею подготовлен проект решения «Об использовании предварительной информации, представленной в виде электронного документа, о товарах, предполагаемых к ввозу на таможенную территорию Евразийского экономического союза» [16].

Возможность представления участниками ВЭД в электронной форме предварительной информации о товарах и транспортных средствах до пересечения ими таможенной границы Российской Федерации с использованием сети Интернет обеспечивает «Личный кабинет участника ВЭД» [28]. Технология предварительного информирования направлена на сокращение времени проведения таможенных формальностей в пунктах пропуска.

В настоящее время введено обязательное предварительное информирование таможенных органов о товарах, ввозимых автомобильным, водным, воздушным и железнодорожным транспортом (98\% предварительной информации подается до прибытия товаров и транспортных средств), это позволило таможенным органам заранее провести анализ данной информации с использованием системы управления рисками.

Подача декларации в электронной форме сопряжена с ее автоматической регистрацией. Кроме того, пункт 6 ст. 310 ТК ЕАЭС устанавливает возможность осуществления таможенного контроля посредством информационной системы таможенных органов без участия должностных лиц таможенных органов. Такая технология по своей сути заключается в удаленном (автоматическом) выпуске товаров. Введение данной законодательной нормы вызвано потребностью участников ВЭД максимально сократить время на совершение таможенных операций и исключить возможность злоупотребления полномочиями должностных лиц таможенных органов при принятии решений, а также необходимостью повысить эффективность деятельности таможенных органов в условиях оптимизации штатной численности сотрудников. Результатом реализации указанной нормы является автоматическая регистрация таможенных документов и автоматический выпуск товаров в соответствии с заявленной таможенной процедурой [14]. Основное преимущество данной технологии заключается в сокращении временного периода при проверке документов, на основании которых заполнена таможенная декларация.

При проверке декларации информационная система в автоматическом режиме определяет соблюдение условий помещения товаров под заявленную таможенную процедуру, установленных запретов и ограничений, прав интеллектуальной собственности, классификационный код товара, страну происхождения товара, таможенную стоимость, правильность исчисления и своевременность уплаты таможенных платежей. Также для автоматического выпуска товаров информационная система проверяет таможенную декларацию на наличие возможных рисков с целью исключения вероятности нарушения таможенного законодательства. Технология автоматической регистрации применяется в отношении таможенных процедур экспорта, выпуска для внутреннего потребления и свободной та- 
моженной зоны в отношении Калининграда. В целях создания единого информационного пространства для обеспечения взаимодействия всех участников обработки грузов в морских портах ФТС России разработан портал «Морской порт» [18].

В 2017 году среднее время автоматической регистрации деклараций на товары составило 3 мин, а их автоматического выпуска -5 мин. В целом за период с 2014 по 2017 годы количество автоматически зарегистрированных деклараций увеличилось почти в 9 раз, а автоматически выпущенных - в 56 раз [17].

Введение обязательного электронного декларирования дало возможность перейти к технологии автоматического выпуска в отношении товаров, по которым в автоматическом режиме не выявлены риски. Осуществление автоматического выпуска товаров без участия должностных лиц таможни стало возможным благодаря разработанной в ФТС России технологии автоматического совершения таможенных операций по выпуску отдельных категорий товаров. Она предполагает тесное взаимодействие информационных систем, используемых таможенными органами и применяемых при совершении таможенных операций по выпуску товаров.

Внедрение электронного декларирования ускорило развитие процессов удаленной уплаты таможенных платежей. С 2001 г. в таможенных органах активно применяются способы уплаты таможенных платежей, основанные на применении специализированных микропроцессорных банковских карт (таможенных платежных карт). Заинтересованность участников ВЭД в использовании этого инструмента платежа, широкое применение в банковской сфере технологий интернет-платежей и мобильных устройств оплаты создали объективные предпосылки для дальнейшего расширения в таможенной сфере современных высокотехнологичных способов и средств платежа. Удаленная уплата таможенных платежей дает возможность плательщику осуществить уплату таможенных платежей, применяя электронный терминал, непосредственно со своего рабочего места. При этом необходимо указать в декларации на товары, поданной в электронном виде, специальный признак удаленной уплаты таможенных платежей. В результате внедрения данной технологии отсутствует необходимость представления декларантом в таможенный орган документов, подтверж- дающих уплату, исключается непосредственный контакт должностных лиц таможенных органов с участниками ВЭД, а списание таможенных платежей по декларациям на товары обеспечивается строго с чеков, указанных в соответствующей графе декларации на товары.

Уплата таможенных платежей через электронные или платежные терминалы, банкоматы предусмотрена ст. 28 Закона о таможенном регулировании, а технология и порядок такой уплаты определяется распоряжением ФТС России [32]. Для упрощения процесса уплаты таможенных платежей при поддержке ФТС России и Национальной ассоциации таможенных представителей применяются единая электронная система ООО «Таможенная карта» [39] и ООО «Мультисервисная платежная система» [38].

Применение технологии удаленной уплаты таможенных платежей ориентировано на упрощение процесса оплаты, а также сокращение временных и финансовых издержек при совершении таможенных операций.

Предоставление таможенными органами государственных услуг (функций) в электронном виде также предоставляет возможность частным субъектам использовать цифровые методы и технологии. В числе таких функций и реализация таможенными органами разрешительной функции, заключающейся во включении в реестры ФТС России лиц, осуществляющих деятельность в области таможенного дела, а также производства контроля за соблюдением условий их осуществления.

В настоящее время в системе таможенных органов действует автоматизированная подсистема «Личный кабинет участника ВЭД» [20]. ФТС России расширяет функциональные возможности сервиса «Лицевой счет», который является наиболее востребованным у плательщиков: в настоящее время 45 тысяч пользователей используют его возможности для оперативного контроля движения денежных средств. Участники ВЭД получают актуальные справочные сведения о задолженности по таможенным платежам и пеням, а также информационные сообщения с реквизитами документа начисления, требованиями об уплате и уведомлениями о взыскании таможенных платежей и пеней. В «Личном кабинете участника ВЭД» действуют более 30 информационных сервиса: «Электронное декларирование товаров», «Электронный архив», «Предварительное информирование», «Стати- 
стическое декларирование», «Лицевой счет», «Валютный контроль», «Разрешительные документы», «Задолженности и штрафы физических лиц», «Запрос статуса задекларированного товара», «Таможенный транзит», «Предварительное информирование в морских портах», «Информирование о декларировании без соглашений», «Отчетность по СВХ», «Отчетность УЭО», «Отчетность владельца таможенного склада», «Отчетность владельца магазина беспошлинной торговли», «Таможенный перевозчик», «Правообладатели», «Личный кабинет банка», «Таможенный представитель», «Получение разрешений, администрирование (ОЭЗ, ПОЭЗ)», «Решение по классификации товаров», «Классификация товаров, перемещаемых в виде компонентов», «Таможенная проверка», «Административные правонарушения», «Калькулятор таможенных платежей», «Пассажирская декларация», «Электронное декларирование экспресс-грузов», «Отчетность импортеров табачных изделий», «Информирование о декларировании по соглашениям», «Помещение товаров на СВХ», «Категорирование» и «Оплата таможенных квитанций».

Например, цель сервиса «Личный кабинет банка»- оперативное информирование банков, включенных в реестр банков, иных кредитных организаций, обладающих правом выдачи банковских гарантий уплаты таможенных пошлин, налогов, о состоянии выданных ими банковских гарантий. Сервис позволяет банку, иной кредитной организации получать сведения об использовании им максимальных сумм всех одновременно действующих банковских гарантий, принятых таможенными органами для обеспечения уплаты таможенных пошлин, налогов.

Сервис «Таможенный представитель» оптимизирует электронное взаимодействие таможенных органов и таможенных представителей. Он содержит сведения о соблюдении организацией условий нахождения в реестре таможенных представителей, а также информацию о статусе рассмотрения ФТС России поданного в электронной форме заявления на предоставление соответствующей государственной услуги.

Ресурс интегрирует в себе возможности сервиса «Отчетность о деятельности таможенного представителя», а также обеспечивает переход в раздел Единого портала государственных и муниципальных услуг (функций), предназначенного для подачи участниками ВЭД в ФТС России заявлений на осуществление государственной услуги по ведению реестра таможенных представителей. Таможенный представитель может просматривать сведения о наличии задолженности, штрафов по делам об административных правонарушениях, а также о предоставленном обеспечении [44].

Переход на массовое использование в таможенной сфере цифровых технологий предопределил начало в 2018 году работы по созданию единой сети электронных таможен и центров электронного декларирования, расширение практики автоматической регистрации деклараций на товары и их автоматического выпуска, совершенствование программных средств таможенных органов [45].

Комплексная программа развития Федеральной таможенной службы на 2018-2020 гг. подразумевает, что все оформление будет проводиться в электронных центрах. С учетом развития современных информационных технологий и ресурсов эта программа предполагает создание территориально распределенных таможенных постов - Центров электронного декларирования. Электронные таможни создаются для упрощения совершения таможенных операций, концентрации таможенного оформления в одном месте, тем самым снижая влияние человеческого фактора и коррупционных рисков.

Таким образом, все взаимодействие и документооборот между таможенными органами и участниками ВЭД будут переведены в электронный формат. Первая в Российской Федерации электронная таможня появилась в Нижнем Новгороде в октябре 2018 г. (Приволжская электронная таможня), поскольку данный федеральный округ входит в эксперимент по созданию одной из первых в стране электронных таможен [22]. Предполагаемый объем ежедневного декларационного массива в данной таможне составит примерно 1500 деклараций. В ней уже сконцентрированы отделы документального контроля четырех таможенных постов Нижегородской таможни, которые исполняют функции, связанные с декларированием товаров.

В Московской областной таможне создана система, позволяющая проводить видеоконтроль за ходом досмотров и других операций фактического контроля. А в течение двух лет система непрерывного видеоконтроля таможенных операций будет введена по всей стране [10]. Это позволяет фиксировать действия должност- 
ных лиц таможенных органов, обоснованность и полноту контроля, сроки его производства. Таким образом, за работой таможенников даже в самых удаленных точках региона можно будет наблюдать в режиме реального времени.

Предпринимаемые ФТС России меры по сокращению времени на проведение таможенных операций, расширение электронного таможенного транзита и внедрение современных информационных технологий ведут к существенному снижению временных и финансовых издержек участников ВЭД и способствуют укреплению конкурентоспособности российского бизнеса.

В последние годы состояние развития цифровых методов и технологий в таможенной сфере в России характеризуется рядом особенностей, тенденций и проблем, которые требуется учитывать для определения перспектив их использования в системе таможенного контроля. Стремительная интеграция российской экономики в глобальную экономику, расширение таможенной границы актуализируют научные исследования, направленные на улучшение таможенного контроля и совершенствование предоставляемых таможенных услуг посредством улучшения информационных технологий $[1,3,7$, $8,15]$.

Широкое применение информационных систем и технологий без использования средств защиты представляется довольно опасным. Отсутствие должного внимания к данной проблеме в дальнейшем может привести к незащищенности системы ВЭД перед угрозами неправомерного доступа, копирования и изменения информации, представленной в электронном виде. Эффективность интернет-коммуникаций, развитие информационных технологий в работе таможенных органов немыслимы без решения вопросов информационной безопасности [46].

В целях совершенствования обеспечения информационной безопасности таможенных органов, в том числе защиты сведений, составляющих государственную тайну, на основании Концепции обеспечения информационной безопасности таможенных органов Российской Федерации на период до 2020 г., создан Совет по обеспечению информационной безопасности таможенных органов Российской Федерации [27]. Еще в 1995 году в структуре региональных таможенных управлений были сформированы подразделения информационной безопасности и технической защиты информации, наделенные функциями по технической защите инфор- мации в таможенной сфере. Со временем функции и задачи технической защиты информации значительно расширились, что стало результатом развития структуры и функций таможенной службы, совершенствования информационной-телекоммуникационной инфраструктуры ЕАИС таможенных органов, расширения международного информационного взаимодействия и внедрения перспективных информационных таможенных технологий. Важной задачей является интегрирование информационных ресурсов таможенных органов в государственные информационные системы и логистические информационные системы участников ВЭД.

Функционирование Евразийского экономического союза предполагает и необходимость создания единого информационного пространства, содержащего сведения для таможенных целей. Совершение участниками ВЭД действий посредством применения цифровых технологий в Российской Федерации, должно коррелировать возможности осуществления аналогичных мер и в других государствах-членах ЕАЭС. Кроме того, таможенные органы государств-членов ЕАЭС при осуществлении таможенного контроля должны владеть необходимой информацией о товарах и совершаемых с ними операциях на всей союзной территории.

К сожалению, до настоящего времени в этой области не решены многие проблемы. Таковой, например, является отсутствие взаимного признания государствами ЕАЭС электронной цифровой подписи, что служит препятствием для доступу потенциальных поставщиков к участию в закупках в электронном формате. Евразийской экономической комиссии поручено разработать планы мероприятий по взаимному признанию государствами-членами ЕАЭС электронной цифровой подписи в рамках формирования трансграничного пространства доверия.

Особую значимость приобретают и проблемы, требующие незамедлительного устранения при их возникновении: технические сбои в системе, ошибки эксплуатации системы, кибератаки, нарушение режима конфиденциальности, злонамеренные действия лиц. В данной связи эффективное управление информационными системами, надлежащее их администрирование - залог успешной работы всей таможенной службы в целом.

В данной связи Высшим Евразийским экономическим советом были утверждены Основные направления реализации цифровой повестки 
Евразийского экономического союза до 2025 года [33]. Цели реализации цифровой повестки заключаются в актуализации сложившихся механизмов интеграционного сотрудничества в рамках Союза с учетом глобальных вызовов цифровой трансформации, в обеспечении качественного и устойчивого экономического роста государств-членов, в том числе для ускоренного перехода экономик на новый технологический уклад, формирования новых индустрий и рынков, развития трудовых ресурсов. Реализация цифровой повестки позволит синхронизировать цифровые трансформации и сформировать условия для развития отраслей будущего в государствах-членах ЕАЭС. С помощью такой технологии возможно обеспечить прослеживаемость прохождения товаров по таможенной территории ЕАЭС.

Евразийской экономической комиссией планируется разработка концепции экосистемы цифровых транспортных коридоров ЕАЭС. Создание этой системы способствует формированию общего рынка транспортных услуг и единого транспортного пространства ЕАЭС, реализации транзитного потенциала Союза, совершенствованию контрольно-надзорных функций на транспорте, снижению административных барьеров, ускорению окупаемости инфраструктурных проектов, повышению эффективности, доступности и безопасности транспортных услуг и снижению их себестоимости.

Важным направлением деятельности Евразийской экономической комиссии следует признать развитие механизма «единого окна», предполагающего охват всего процесса ведения бизнеса на территории ЕАЭС: регистрация хозяйствующего субъекта; поиск партнеров; заключение и совершение внешнеторгового контракта; выпуск товара в оборот; налоговый аудит. Для ведения внешнеэкономической деятельности предпринимателю необходимо будет сделать в информационной системе семь шагов: зарегистрироваться в системе и сформировать личный кабинет участника ВЭД, найти партнера, заключить контракт онлайн, выполнить финансовые обязательства (оплата товаров и услуг, таможенные платежи и пр.), активизировать данные, провести мониторинг движения товаров, выполнить учет и контроль [6]. Механизм «единого окна» станет первым сервисом для бизнеса, в котором предприниматели получат удаленный доступ сразу ко всем органам исполнительной власти, задействованным в системе регулирования ВЭД. Для этого необходимыми факторами станут лишь желание самого лица и доступ в интернет.

Предполагается, что цифровая трансформация рынка товаров и услуг приведет к значительному упрощению торговых процедур путем перехода в цифровую форму, активному использованию электронной торговли, а также к эффективной реализации и использованию механизмов «единого окна» в сфере экономики. Это потребует проведения дальнейшей гармонизации в сфере правил ведения трансграничной электронной торговли, стимулирования ведения бизнеса в цифровой форме, координации действий в сфере защиты прав на объекты интеллектуальной собственности и прав потребителей цифрового рынка, а также включения вопросов регулирования сотрудничества в сфере цифровой экономики в повестку дня торговых переговоров Союза с третьими странами.

Таким образом, в настоящее время прослеживается тенденция развития инструментов электронного декларирования товаров, создания информационно-технических условий для автоматизированного принятия решений в отношении декларантов, более активного использования механизма предварительного информирования, совершенствования информационно-технических условий для оказания таможенных услуг и проведения таможенного контроля путем обеспечения межведомственного взаимодействия, совершенствования информационно-технических условий использования системы управления рисками в целях минимизации расходов по проведению таможенного контроля и повышения определения случаев недобросовестного экономического поведения участников ВЭД.

Внедрение цифровых методов и технологий в таможенной сфере позволило ФТС России при обеспечении поддержки собственных таможенных процессов и содействии международной торговле создать благоприятные условия для международного товарооборота, минимизировать влияние человеческого фактора на таможенные процессы, сократить расходы на государственное управление. Разработка и внедрение информационных технологий в таможенной сфере - своевременный и необходимый процесс, который позволяет повысить качество и оперативность совершения таможенных операций. 


\section{Библиографический список}

1. Агамагомедова С.А., Курдина Н.В. Развитие информационных технологий в таможенном деле // Таможенное дело и внешнеэкономическая деятельность компаний. 2017. № 1 (2). С. 418-432.

2. Амелин Р.В. Государственные и муниципальные информационные системы в российском информационном праве: теоретико-правовой анализ: монография / Под ред. С.Е. Чаннова. М.: ГроссМедиа, 2018. С.7-16.

3. Барбышева Г.И., Мешвелиани Н.Б. Совершенствование таможенного декларирования и таможенного контроля в результате внедрения новых информационных технологий // Научная дискуссия: инновации в современном мире. 2016. № 7 (50). С. 93-98.

4. Емельянова Н.3. Основы построения автоматизированных информационных систем: Учебное пособие / Н.3. Емельянова, Т.Л. Партыка, И.И. Попов.- М.: Форум: Инфра-М, 2015. С. 215.

5. Зуева Т.С. Особенности внедрения электронного декларирования в работу участников внешнеэкономической деятельности и таможенных органов на территории России // Таможенное дело. 2014. № 2. С. 3-6.

6. Информация опубликована на официальном сайте Евразийской экономической комиссии. Cм.: http:// www.eurasiancommission.org/ru/nae/news/Pages/13-07-2018-3.aspx (дата обращения 06.04.2019)

7. Клязьмина А.И. Информационные технологии как направление повышения результативности таможенного контроля // Научный журнал «Дискурс». 2016. № 2 (2). С. 450-457.

8. Концепции системы предварительного информирования таможенных органов Российской Федерации, утв. приказом ФТС России от 10 марта 2006 г. № 192 // Таможенный вестник. 2006. № 7.

9. Корняков К.А. Перспективы использования новых технологий как средств модернизации таможенного контроля товаров в условиях Таможенного союза // Таможенное дело. 2011. № 4. С. 33-38.

10. Куликов С. Сам себе режиссер. ФТС начала снимать все досмотры на камеру // Рос.газета. 2018. 8 июля.

11. Куптель E. В. Информационные технологии как незаменимый инструмент в работе менеджера по таможне. URL: https:/interactive-plus.ru/ru/article/118908/discussion_platform (дата обращения: 03.07.2018).

12. Макарова Г.В., Тиницкая О.В. Электронный документооборот как основа развития таможенных операций // Российский внешнеэкономический вестник. 2014. № 1. С. 71-81.

13. Международная конвенция об упрощении и гармонизации таможенных процедур: совершено в Киото 18 мая 1973 г. (в ред. Протокола от 26 июня 1999 г.). Ратифицирована Федеральным законом от 3 ноября 2010 г. № 279-ФЗ // СЗ РФ. 2011. № 32. Ст. 4810.

14. Немирова Г.И., Ермакова А.А. Состояние и перспективы развития информационных технологий в системе таможенного контроля // Таможенное дело. 2018. № 1. С.12.

15. Новикова С.А., Сураева В.Р. Внедрение информационных электронных технологий как фактор совершенствования таможенного администрирования // ФЭС: Финансы. Экономика. 2015. № 1. С. 33-37.

16. Официальный сайт Евразийской экономической комиссии. URL: http://www.eurasiancommission.org/ru/act/ tam_sotr/dep_tamoj_infr/SiteAssets/Pages/pr_inf/\%D0\%9F\%D0\%BE\%D1\%80\%D1\%8F\%D0\%B4\%D0\%BE\%D0\% BA\%20\%D0\%B8\%D1\%81\%D0\%BF\%D0\%BE\%D0\%BB\%D1\%8C\%D0\%B7\%D0\%BE\%D0\%B2\%D0\%B0\%D0\%BD\%D0 \%B8\%D1\%8F_13.06.2018.pdf (дата обращения: 05.04.2019).

17. Официальный сайт ФТC России. URL: http://customs.ru/index.php?option=com_ content\&view=article\&id=26346: $-35------2017-\& c a t i d=40: 2011-01-24-15-02-45$ (дата обращения: 05.04.2019).

18. Официальный сайт ФТС России. URL: http://sea.customs.ru (дата обращения: 05.04.2019).

19. Официальный сайт ФТС России. URL: http://www.customs.ru/index.php?option=com_ content\&view=article\&id=18560:-1-2014-_--_\&catid=40:2011-01-24-15-02-45 (дата обращения: 05.04.2019).

20. Официальный сайт ФТС России. URL: https://edata.customs.ru/FtsPersonalCabinetWeb (дата обращения: 06.04.2019).

21. Портал предварительного электронного представления сведений физическими лицами в таможенные органы. URL: http://93.84.112.51:8081/EpiFiz/ (дата обращения: 04.04.2019).

22. Порядка 1500 деклараций будет ежедневно оформлять Приволжская электронная таможня.URL: Официальный сайт ФТС России http://www.customs.ru/index.php?option=com_content\&view=article\&id=26484:1500----\&catid=40:2011-01-24-15-02-45\&Itemid=2094\&Itemid=1835 (дата обращения: 07.07.2018). 
23. Приказ Минфина России от 30 августа 2016 г. № 144н «Об утверждении Порядка использования Единой автоматизированной информационной системы таможенных органов при таможенном контроле, таможенном декларировании и выпуске (отказе в выпуске) товаров, помещаемых под таможенную процедуру таможенного транзита, в электронной форме». URL: Официальный интернет-портал правовой информации http://www.pravo.gov.ru (дата обращения: 05. 04. 2019).

24. Приказ ФТС России от 17 июня 2010 г. № 1154 (с изм. и доп. от 18 сентября 2012 г.) «Об утверждении Положения о Единой автоматизированной информационной системе таможенных органов» // СПС «КонсультантПлюс» (дата обращения: 04.04.2019).

25. Приказ ФТС России от 17 сентября 2013 г. № 1761 «Об утверждении Порядка использования Единой автоматизированной информационной системы таможенных органов при таможенном декларировании и выпуске (отказе в выпуске) товаров в электронной форме, после выпуска таких товаров, а также при осуществлении в отношении них таможенного контроля» // Рос. газета. 2014. № 56.

26. Приказ ФТС России от 21 октября 2015 г. № 2133 «Об утверждении основных направлений развития информационно-коммуникационных технологий в таможенных органах Российской Федерации до 2030 года» // Таможенные ведомости. 2016. № 1.

27. Приказ ФТС России от 22 августа 2011 г. № 1702 «Об утверждении Положения и состава Совета по обеспечению информационной безопасности таможенных органов Российской Федерации». URL: http://customs. ru/images/stories/GROUPS/sndt9fc7.pdf (дата обращения: 06.04.2019).

28. Приказ ФТС России от 24 января 2008 г. № 52 «О внедрении информационной технологии представления таможенным органам сведений в электронной форме для целей таможенного оформления товаров, в том числе с использованием международной ассоциации сетей «Интернет»» // Рос. газета. 2008. 1 марта.

29. Распоряжение Правительства РФ от 1 ноября 2013 г. № 2036-р «Об утверждении Стратегии развития отрасли информационных технологий в Российской Федерации на 2014-2020 годы и на перспективу до 2025 года» // СЗ РФ. 2013. № 46. Ст. 5954.

30. Распоряжение Правительства РФ от 14 декабря 2005 г. № 2225-р «О Концепции развития таможенных органов Российской Федерации» // СЗ РФ. 2006. № 2. Ст. 260.

31. Распоряжение Правительства РФ от 28 декабря 2012 г. № 2575-р (с изм. и доп. от 10 февраля 2018 г. № $207-$ р) «О Стратегии развития таможенной службы Российской Федерации до 2020 года» // СЗ РФ. 2013. № 2. Ст. 109; 2018. № 8. Ст. 1254.

32. Распоряжение ФТС России от 19 декабря 2013 г. № 406-р (с изм. и доп. от 5 июня 2014 г.) «Об утверждении Временного порядка действий должностных лиц таможенных органов при удаленной уплате таможенных платежей лицами, осуществляющими декларирование товаров в электронной форме, с использованием электронного терминала» // СПС «КонсультантПлюс» (дата обращения: 06.04.2019).

33. Решение Высшего Евразийского экономического совета от 11 октября 2017 г. № 12 «Об Основных направлениях реализации цифровой повестки Евразийского экономического союза до 2025 года» // Официальный сайт Евразийского экономического союза http://www.eaeunion.org/, (дата обращения: 05.04.2019).

34. Решение Коллегии Евразийской экономической комиссии от 19 декабря 2017 г. № 188 «О некоторых вопросах, связанных с выпуском товаров» (вместе с «Порядком совершения таможенных операций, связанных с выпуском товаров, отказом в выпуске товаров и аннулированием выпуска товаров, оформления решений о приостановлении срока выпуска товаров, продлении срока такого приостановления и об их отмене, а также уведомления о принятии таких решений») // Официальный сайт Евразийского экономического союза http://www.eaeunion.org/ (дата обращения: 04.04.2019).

35. Решение Комиссии Таможенного союза от 8 декабря 2010 г. № 494 «Об Инструкции о порядке предоставления и использования таможенной декларации в виде электронного документа». URL: Официальный сайт Комиссии Таможенного союза http://www.tsouz.ru/ (дата обращения: 05.04.2019).

36. Решение Комиссии Таможенного союза от 9 декабря 2011 г. № 899 «О введении обязательного предварительного информирования о товарах, ввозимых на таможенную территорию Таможенного союза автомобильным транспортом» // СПС «Консультант Плюс».

37. Решение Совета Евразийской экономической комиссии от 22 августа 2017 г. № 100 «Об утверждении Стратегии развития интегрированной информационной системы Евразийского экономического союза на период до 2025 года». URL: Официальный сайт Евразийского экономического союза http://www.eaeunion.org/ (дата обращения: 05.04. 2019).

38. Сайт платежной системы «Мультисервисная платежная система». URL: http://www.payhd.ru/ (дата обращения: 06.04.2019). 
39. Сайт платежной системы «Таможенная карта». URL: https://www.customscard.ru/ (дата обращения: 06.04.2019).

40. Таможенный кодекс Евразийского экономического союза (приложение № 1 к Договору о Таможенном кодексе Евразийского экономического союза). URL. Официальный сайт Евразийского экономического союза http://www.eaeunion.org/ (дата обращения: 05.04. 2019).

41. Федеральный закон от 27 ноября 2010 г. № 311-Ф3 (с изм. и доп. от 29 декабря 2017 г.) «О таможенном регулировании в Российской Федерации» // СЗ РФ. 2010. № 48. Ст. 6252; 2018. № 1. (ч. 1). Ст. 54. В настоящее время в основной части утратил силу.

42. Федеральный закон от 3 августа 2018 г. № 289-Ф3 «О таможенном регулировании в Российской Федерации и о внесении изменений в отдельные законодательные акты Российской Федерации» // СЗ РФ. 2018. № 32 (ч.1). Ст.5082.

43. Федеральный закон от 6 апреля 2011 г. № 63-Ф3 «Об электронной подписи» (с изм. и доп. от 23 июня 2016 г.) // СЗ РФ. 2011. № 15. Ст. 2036; СЗ РФ. 2016. № 26. Ч. 1. Ст. 3889.

44. ФTС России запустит два новых сервиса в «Личном кабинете участника ВЭД». URL: Официальный сайт ФТС России: http://www.customs.ru/index.php?option=com_content\&view=article\&id=26363:----1-r\&catid=40:2011-01-24-15-02-45\&Itemid=2094\&Itemid=1835 (дата обращения: 06.04.2019).

45. ФТС России: 3-5 минут составило среднее время автоматической регистрации и выпуске товаров в 2017 году. URL: Официальный сайт ФТС России http://www.customs.ru/index. php?option $=$ com_content \&view $=$ article $\&$ id $=26346:-35------2017-\&$ catid $=40: 2011-01-24-15-02-$ 45 \&Itemid=2094\&Itemid=1835 (дата обращения: 05.04.2019).

46. Чеботарева А.А. Интернет-коммуникации таможенных органов с гражданами и участниками внешнеэкономической деятельности: вопросы информационной открытости и эффективного взаимодействия при соблюдении информационной безопасности // Таможенное дело. 2016. № 3. С. 33-36. 